\title{
Efektywność dzialania specjalnych stref ekonomicznych, parków naukowo-technologicznych i parków przemysłowych w świetle zapotrzebowania przedsiębiorstw na kadry na przykładzie województwa śląskiego i podkarpackiego
}

Państwa rozwinięte w najbliższych dekadach muszą się liczyć z postępowaniem procesu automatyzacji, robotyzacji i komputerowego sterowania produkcją, który ograniczy zapotrzebowanie na pracowników, zwłaszcza produkcyjnych. Jednocześnie pracochłonna produkcja materialna przesuwana jest z krajów bardziej rozwiniętych, o wyższych kosztach pracy, do państw, gdzie koszty te są znacznie niższe. Sektor usługowy w dużej mierze nie podlega tym przemianom. Wynika to ze specyfiki podstawowych cech usług, takich jak niematerialność, nieskładowalność czy też jedność procesu świadczenia i konsumpcji. Dlatego też trudno mówić o przesunięciach w takich zawodach jak hydraulik, elektryk, fryzjer, architekt, mechanik, dentysta. Warto także zwrócić uwagę na fakt, iż różnice kulturowe i językowe będące naturalnym hamulcem dla procesów globalizacji produkcji, powodują, że nie zanikają zawody wymagające kreatywności, oryginalności, indywidualnego myślenia i wytwarzania (Cyrson 2009, Timmermans 2005).

Jedna z najbardziej uznanych firm świadczących usługi z zakresu konsultingu - Accenture ${ }^{1}$ - przewiduje, że w następnych latach w Europie zwiększy się zapotrzebowanie na pracowników w takich rodzajach działalności, jak: aeronautyka, bankowość i ubezpieczenia, obrona terytorialna, ekogospodarka, ochrona zdrowia, technologie informacyjne, farmaceutyka, bezpieczeństwo sieci internetowej, usługi społeczne, w tym opieka nad osobami starszymi i dziećmi, transfer usług edukacyjnych przy wykorzystaniu narzędzi cyfrowych, rozwój sieci dla globalnych przedsiębiorstw, w tym środki audiowizualne, nowoczesny szybki transport oraz turystyka. Natomiast będą wzrastały kłopoty ze znalezieniem zatrudnienia w public relations, marketingu czy reklamie. Zaciskanie pasa przez firmy wiąże się ze znacznym uszczupleniem budżetów na wszelkie działania promocyjno-reklamowe. Skutkiem tego już zmniejsza się liczba wakatów na stanowiskach związanych z tego typu działalnością. Ze względów oszczędnościowych, firmy zlecają część usług jednostkom zewnętrznym, przez co dochody i zatrudnienie w firmach outsourcingowych sukcesywnie rosną. Dotyczy to zwłaszcza tych firm, które specjalizują się w finansach, telekomunikacji i zaawansowanych technologiach.

\footnotetext{
${ }^{1}$ Źródła i strategie innowacyjności przedsiębiorstw, 2005. Projekt badawczy zrealizowany przez The Conference Board, we współpracy z Instytutem Nauk Ekonomicznych Polskiej Akademii Nauk oraz firmami Accenture i House of Skills.
} 
W niniejszym artykule przedstawiono wyniki badań sondażowych, które miały zidentyfikować trendy rynku pracy i przyszłe zapotrzebowanie pracodawców, w tym także inwestorów, na pracowników (z określeniem wymaganych kwalifikacji i poziomu praktycznego przygotowania do wykonywania zawodu) w perspektywie krótkoterminowej (do 1 roku) w województwie śląskim i podkarpackim.

\section{Ustalenia badawcze}

Badania zostały przeprowadzone w sierpniu 2009 r. za pomocą samokodującego standaryzowanego kwestionariusza realizowanego metodą wywiadu bezpośredniego wśród pracodawców oraz inwestorów funkcjonujących w następujących strefach/parkach obu wymienionych województw:

a) SSE EURO-PARK MIELEC,

b) Tarnobrzeska SSE EURO-PARK WISŁOSAN,

c) Mielecki Park Przemysłowy,

d) Żorski Park Przemysłowy,

e) Śląski Park Przemysłowy,

f) Górnośląski Park Przemysłowy,

g) Jaworznicki Park Przemysłowy,

h) Częstochowski Park Przemysłowy,

i) Bytomski Park Przemysłowy,

j) Bielski Park Technologiczny,

k) Beskidzki Inkubator Technologiczny,

1) Rybnicki Inkubator Technologiczny,

m) Euro-Centrum Park Przemysłowy,

n) Park Przemysłowy - Piekary Śląskie.

Warto podkreślić, że podjęta została próba dotarcia do wszystkich podmiotów gospodarczych działających na terenie wyżej wymienionych stref/parków. Badania udało się przeprowadzić w $181 \mathrm{z}$ nich ${ }^{2}$. Dodatkowo badania kwestionariuszowe przeprowadzono także w 100 losowo wybranych firmach ${ }^{3}$ działających na terenie badanych województw poza strefami/parkami (grupa porównawcza).

\footnotetext{
${ }^{2}$ We wszystkich strefach, parkach i inkubatorach na terenie województw podkarpackiego i śląskiego zlokalizowanych jest 356 podmiotów. W związku z powyższym, w kontekście badań ww. obszarów, nie można mówić o reprezentatywności uzyskanych wyników, lecz o opisie populacji. Przedstawione dane są najpełniejsze z możliwych do uzyskania przy obecnym zaangażowaniu przedsiębiorców. Można zatem powiedzieć, że w odniesieniu do firm ze stref/parków/inkubatorów dane te są kompletne i nieobciążone błędem losowym. Wyniki te są z kolei obciążone błędem systematycznym o trudnej dla oszacowania skali (wynikającym z odmów udziału w badaniach). Z tego względu wyniki opisywane w wartościach bezwzględnych można określić jako minimalne, tzn. jeżeli w okresie 12 miesięcy przebadane firmy deklarują zgłoszenie zapotrzebowania na 150 pakowaczy, to należy się spodziewać, że w podmiotach na terenie obszarów specjalnych w okresie 12 miesięcy zostanie utworzonych 150 lub więcej miejsc pracy dla pakowaczy.

${ }^{3}$ Podmioty spoza stref/parków zostały wybrane w sposób losowy (dobór systematyczny na uporządkowanym pod względem sekcji i powiatu operacie bazującym na ewidencji REGON). W efekcie wyniki otrzymane dla podmiotów spoza ww. obszarów obciążone są błędem losowym około $+/-10 \%(9,8 \%)$. Porównując wyniki pomiędzy podmiotami ze stref/parków oraz spoza nich, można przyjąć ogólną zasadę (szczegółowo jest to zawsze weryfikowane odpowiednim testem), że jeżeli różnice pomiędzy wynikami dla obu grup są większe niż 10\%, to istnieją różnice pomiędzy tymi grupami firm.
} 


\section{Wyniki badań ankietowych \\ Plany zatrudnienia}

Na plany zatrudnienia pracowników najsilniej wpływa zasięg działania firmy. Wśród firm, które deklarują działanie na skalę międzynarodowa, 65\% planuje zatrudnienie nowych pracowników. Z kolei wśród firm działających lokalnie lub regionalnie plany takie ma 24\%. Pomiędzy firmami działającymi na skalę ogólnopolską różnice w planach zatrudnienia nowych pracowników wynikają z sektora, w którym podmioty te działają. Dwie trzecie firm z sektora I lub II (sekcje A do F wg PKD 2004) planuje zwiększenie zatrudnienia. Natomiast wśród firm z sektora III (pozostałe sekcje PKD 2004) plany takie ma jedna trzecia firm.

Różnorodność stanowisk, na które planowane jest zatrudnienie pracowników, zależy od wielkości firmy. Im przedsiębiorstwo większe, tym na więcej różnych stanowisk pracy będzie prowadziło rekrutację w okresie najbliższych 12 miesięcy.

W okresie najbliższych 12 miesięcy firmy działające w strefach ekonomicznych oraz parkach planują zatrudnić łącznie 638 pracowników. Z tego na Podkarpaciu plany dotyczą 460 osób, zaś na Śląsku - 178. Wskazać można, iż wpływ na plany zatrudnieniowe ma tylko fakt, czy firma działa jedynie w strefie, czy też jest częścią większego podmiotu gospodarczego. W przypadku firm działających w strefie/parku oraz poza nim średnia liczba osób planowanych do zatrudnienia wzrasta o ponad $5 \mathrm{w}$ stosunku do firm działających jedynie $\mathrm{w}$ ramach strefy/parku.

Podmioty działające w strefach ekonomicznych oraz parkach przemysłowych i technologicznych zgłaszać będą zapotrzebowanie przede wszystkim na operatorów i monterów, robotników niewykwalifikowanych oraz, nieco rzadziej, na specjalistów. Firmy te nie będą generowały stanowisk pracy w biurach oraz stanowisk o charakterze usługowym bądź handlowym. Pod tym względem zasadniczo różnią się od firm spoza obszarów specjalnych.

Biorąc pod uwagę firmy ze stref/parków, znaczne różnice występują pomiędzy województwami. Na Śląsku firmy zgłaszać będą większe zapotrzebowanie na specjalistów, z kolei na Podkarpaciu poszukiwani będą przede wszystkim robotnicy wykwalifikowani i niewykwalifikowani. Na różnice te wpływać może przede wszystkim specyfika specjalnych stref ekonomicznych oraz parków przemysłowych i technologicznych, odmienny potencjał i okres ich działania.

Firmy generować będą zapotrzebowanie na bardzo zróżnicowane stanowiska pracy. Cztery stanowiska, na które przyjętych ma być najwięcej osób, to pakowacz, robotnik budowlany, programista i pracownik ochrony.

W przedsiębiorstwach działających na terenie specjalnych stref ekonomicznych oraz parków przemysłowych i technologicznych jest znacznie większe zapotrzebowanie na robotników niewykwalifikowanych, sięgające niemal 30\% w stosunku do 0,4\% w firmach spoza stref/ parków. Podmioty zlokalizowane na Śląsku zgłaszać będą znacznie większe zapotrzebowanie na pracowników z wykształceniem wyższym. Na Podkarpaciu większe będzie zapotrzebowanie na osoby z wykształceniem średnim zawodowym, zasadniczym zawodowym oraz gimnazjalnym i niższym.

Ze zgromadzonych danych wynika, iż pracodawcy, rekrutując na stanowiska z grupy technicy i inny średni personel, będą wymagać od kandydatów wyższego wykształcenia. Może to świadczyć o zdewaluowaniu dyplomów szkół średnich i/lub znacznej nadwyżce podaży nad popytem na regionalnym rynku pracy. Podobna sytuacja, choć mniej wyraźnie, dotyczy stanowisk robotników wykwalifikowanych, na które w 27\% przypadków wymagane będzie wykształcenie średnie (powinno wystarczyć zasadnicze zawodowe), a także robotników niewykwalifikowanych, na które wymagane będzie wykształcenie zasadnicze zawodowe 
(do wykonywania pracy $\mathrm{w}$ tych zawodach nie jest potrzebne przygotowanie zawodowe w szkole). Jeśli teza o dewaluacji dyplomów szkół zawodowych jest słuszna, to może wskazywać na dostrzeganie przez pracodawców niedostosowania przygotowania szkolnego do wymogów rynku pracy. Pracodawcy radzą sobie z tym problemem, podnosząc wymagania kwalifikacyjne w nadziei, że lepsze wykształcenie zmniejszy deficyty w przygotowaniu do pracy zawodowej.

Według uzyskanych wyników, na 54\% stanowisk będzie się można ubiegać o zatrudnienie bez posiadania doświadczenia w pracy zawodowej, zaś 30\% ofert pracy wiązać się będzie z koniecznością posiadania minimum 12-miesięcznego doświadczenia (nie licząc praktyk i staży). Wynika z tego, że pracodawcy nie do końca ufają praktycznemu przygotowaniu uczniów/studentów w szkołach. Posiadanie praktyk i staży jest wystarczającym kryterium przyjęcia jedynie na co siódme stanowisko. Jest to w przybliżeniu miara skuteczności kształcenia zawodowego. Bardzo duży udział skrajnych kategorii wskazuje na to, że pracodawcy albo sami szkolą swoich pracowników, albo poszukują takich, którzy mają już duże doświadczenie w samodzielnej pracy.

Pracowników bez doświadczenia przyjmują firmy, które mogą sobie na to pozwolić: podmioty duże będące własnością zagranicznych inwestorów, działających od dłuższego czasu w Polsce. Działania takie podejmują firmy o obrotach powyżej $10 \mathrm{mln}$ złotych oraz te, które prowadzą działalność nie tylko na terenie stref/parków. Można postawić hipotezę, iż kierownictwo tych firm, opierając się na wcześniejszych/innych doświadczeniach, przyjęło strategię kształcenia kadr na własne potrzeby zgodnie z własnymi wymogami.

Inną strategię rekrutacji pracowników, zmierzającą do poszukiwania osób z dużym doświadczeniem, mają firmy powstałe stosunkowo niedawno (po 2004 roku), o obrotach od 100 tys. do miliona złotych, małe (10-49 pracowników), prowadzące działalność w skali międzynarodowej. Są to przedsiębiorstwa będące w stanie rozwoju, które już mogą sobie pozwolić na poszukiwanie wykwalifikowanej siły roboczej z doświadczeniem w pracy zawodowej (potrzebnej zapewne w kontaktach zagranicznych), ale jeszcze nie wystarczająco bogate, aby mogły sobie pozwolić na kształcenia pracowników pod swoje potrzeby.

Osoby po praktykach lub stażach mają zamiar przyjąć firmy najdłużej funkcjonujące na rynku (tradycja), działające lokalnie, o kapitale w większości polskim, małe, o obrotach do 100 tys. złotych. Można przyjąć hipotezę, iż firmy te, nie mogąc zaoferować warunków oczekiwanych przez doświadczonych pracowników, poszukują takich osób, na które je stać.

\section{Profile kwalifikacji}

Na podstawie opisów stanowisk zawierających zestawy niezbędnych kwalifikacji utworzono zbiorcze zestawienie kwalifikacji. Od największej liczby kandydatów do pracy wymagana będzie umiejętności obsługi komputera. Kolejne kwalifikacje, pod względem liczby pracowników, w stosunku do których będą one wymagane, to doświadczenie zawodowe oraz uprawnienia budowlane, a także uprawnienia do obsługi wózków widłowych, licencja pracownika ochrony, umiejętność obsługi wózka widłowego oraz posiadanie pewnych predyspozycji manualnych.

$\mathrm{Na}$ podstawie analiz stworzono uogólnione profile kwalifikacji poszukiwanych kandydatów w zależności od typu stanowiska, na które będzie prowadzona rekrutacja. Przedstawiają się one następująco:

- Od kierowników wymagane będzie doświadczenie zawodowe oraz znajomość języków obcych.

- Specjaliści poza doświadczeniem zawodowym powinni posiadać także umiejętność obsługi programów komputerowych. 
- Technicy i inny średni personel to osoby, w stosunku do których wymagane będzie doświadczenie oraz specyficzne umiejętności zawodowe tj. umiejętności związane z konkretnym stanowiskiem pracy (zawodem).

- W stosunku do pracowników biurowych wymagane będzie przede wszystkim posiadanie specyficznych cech osobowych oraz umiejętność obsługi specjalistycznych maszyn i urządzeń.

- W stosunku do pracowników usług osobistych i sprzedawców stawiany będzie wymóg posiadania uprawnień, certyfikatów i licencji, także uzależnionych od konkretnego stanowiska pracy (zawodu) oraz posiadanie odpowiedniego poziomu wykształcenia.

- Legitymowanie się uprawnieniami, certyfikatami i licencjami oraz specyficznymi umiejętnościami zawodowymi wymagane będzie od robotników przemysłowych i rzemieślników.

- Operatorzy i monterzy maszyn i urządzeń poza uprawnieniami, certyfikatami i licencjami powinni również posiadać umiejętności obsługi specjalistycznych maszyn i urządzeń.

- W przypadku kandydatów do pracy na stanowiskach z grupy pracowników przy pracach prostych nie będą stawiane żadne wymagania.

\section{Stopień i czas dopasowania kształcenia do rekrutacji $i$ zatrudnienia}

Największe trudności przy rekrutacji stanowi 110 różnych zawodów, na których planowane jest zatrudnienie 317 osób. Wśród nich najczęściej wymieniano zawody z grupy robotników przemysłowych i rzemieślników. Na drugim miejscu pod względem liczby wskazań znalazły się stanowiska $\mathrm{z}$ grupy specjalistów.

Wśród firm ze stref/parków częściej wskazywane są stanowiska z grupy robotników przemysłowych i rzemieślników oraz specjalistów. W pozostałych firmach problem dotyczy przede wszystkim pracowników biurowych oraz techników i innego średniego personelu.

W samych strefach/parkach do stanowisk, na które planuje się największe zatrudnienie, a przy których mogą się pojawić problemy ze znalezieniem pracowników, należą programista, magazynier oraz modelarz odlewacz i szwaczka.

Na Śląsku problemy z rekrutacją największej liczby pracowników dotyczyć będą osób na stanowiska z grupy specjalistów (49\%) oraz techników i innego średniego personelu (24\%), zaś na Podkarpaciu na stanowiska z grupy robotnicy przemysłowi i rzemieślnicy (51\%) oraz operatorzy i monterzy maszyn i urządzeń.

Najdłuższy okres przygotowania jest niezbędny dla osób na stanowiska kierownicze. W skali wszystkich badanych podmiotów jest to niemal 11 miesięcy (ponad 31 miesięcy dla firm w SSE/PT/PP). Kolejne pod względem średniej długości przygotowania pracownika są stanowiska z grupy specjalistów - około 9 miesięcy. Trzecią grupą zawodów są pracownicy biurowi - ponad 7 miesięcy. Czwarta grupa to pracownicy usług osobistych i sprzedawcy, których średni okres przygotowania wynosi ponad 5 miesięcy, a piątą grupę stanowią technicy $\mathrm{i}$ inny średni personel, których przygotowanie, zgodnie z deklaracjami, trwa niewiele ponad 5 miesięcy i jest podobnie szacowane w obu grupach firm. Średni okres praktycznego przygotowania pracownika wynosi ponad 6 miesięcy, przy czym 7,5 miesiąca w strefach/parkach oraz 4 miesiące $\mathrm{w}$ pozostałych firmach.

Deklarowane okresy przygotowania pracowników są dłuższe na Podkarpaciu niż na Śląsku. Ogółem średni okres przygotowania pracowników na Podkarpaciu jest o 4 miesiące dłuższy niż na Śląsku i wynosi ponad 9 miesięcy.

Najdłuższy okres przygotowania praktycznego dotyczy zastępcy dyrektora, prezesa do spraw finansowo-administracyjnych, pozostałych operatorów maszyn i urządzeń do obróbki metali, inżynierów automatyki i robotyki, pozostałych inżynierów mechaników, pracowników biurowych, inżynierów budownictwa - budownictwo ogólne. 
Firmy deklarujące, iż będą w najbliższym czasie zatrudniały nowych pracowników, generalnie wyrażają chęć przyjmowania na nowe miejsca pracy absolwentów. Gotowość taką zadeklarowała zdecydowana większość spośród nich, tj. 82\%. Zauważyć można z jednej strony nieznacznie większą gotowość do zatrudniania absolwentów wśród śląskich firm działających na terenie stref/parków niż w przypadku analogicznych firm z obszaru województwa podkarpackiego, z drugiej zaś większą chęć zatrudnienia absolwentów przez firmy prowadzące swoją działalność zarówno na terenie stref, jak i poza nimi w porównaniu z firmami prowadzącymi działalność jedynie na obszarze parków i stref.

\section{Bariery zatrudniania absolwentów w świetle ksztatcenia zawodowego}

Jednostki deklarujące niechęć do zatrudniania absolwentów jako przyczyny tego stanu rzeczy wskazują przede wszystkim czynniki związane z brakiem doświadczenia zawodowego oraz (wiążący się z nim) brak odpowiednich umiejętności zawodowych. Z kolei wśród czynników sprzyjających chęci zatrudnienia absolwentów firmy najczęściej wskazują dwa typy: po pierwsze, są to czynniki związane z młodością absolwentów, przede wszystkim z faktem, iż nie nabrali oni jeszcze negatywnych nawyków związanych z pracą u innych pracodawców, a także otwartość wobec nowych technologii. Po drugie, na czynniki związane z finansowym aspektem ich zatrudnienia (niższe oczekiwania płacowe czy możliwość dofinansowania zatrudnienia). Okazuje się więc, że brak zawodowego doświadczenia jest z jednej strony bariera, z drugiej zaś atutem absolwentów.

O tym, że brak doświadczenia zawodowego jest jedną z ważniejszych barier świadczy fakt, iż podstawowym czynnikiem - zdaniem przedsiębiorców - utrudniającym rekrutację na nowe stanowiska pracy jest brak zawodowego doświadczenia wśród osób o nią się starających. Dominacja tego akurat czynnika wskazuje, iż absolwenci - z definicji pozbawieni wieloletniego doświadczenia zawodowego - mogą mieć bardzo duże problemy z uzyskaniem stałego zatrudnienia.

W konsekwencji, firmy generalnie nie są zainteresowane współpracą ze szkołami w zakresie rekrutacji nowych pracowników. Chęć taką wyraża jedynie 30,1\% ogółu badanych instytucji (32,8\% spośród instytucji prowadzących działalność na terenie stref/parków). Województwo, na terenie którego zlokalizowane są strefy/parki, nie różnicuje deklaracji dotyczących podjęcia współpracy (w przeszłości lub chwili obecnej) ze szkołami zawodowymi. Różnicuje natomiast gotowość do jej podjęcia w przyszłości. Firmy ze stref/parków zlokalizowanych na obszarze województwa podkarpackiego częściej niż instytucje z obszaru województwa śląskiego deklarują gotowość do jej podjęcia (35,7\% wobec 30,2\%). Bardziej szczegółowe analizy wskazują, że firmy mikro i małe częściej niż średnie i duże deklarują brak aktualnej współpracy ze szkołami zawodowymi, połączony z brakiem chęci do jej nawiązania w przyszłości. Firmy średnie częściej niż pozostałe typy instytucji twierdzą, iż wprawdzie jeszcze nie współpracują ze szkołami zawodowymi, lecz gotowe są taką współpracę nawiązać. Z kolei firmy duże nieco częściej niż pozostałe deklarują współpracę ze szkołami zawodowymi w badanym zakresie. Generalnie im więcej osób jest zatrudnionych w badanej instytucji, tym częstsza współpraca ze szkołami zawodowymi, a także częstsza gotowość do jej podjęcia w przyszłości.

Występująca aktualnie współpraca firm z instytucjami edukacyjnymi w zakresie rekrutacji pracowników związana jest przede wszystkim z organizowaniem praktyk zawodowych. Prawdopodobnie praktyki stanowią swoisty filtr, poprzez który weryfikuje się rzeczywiste umiejętności potencjalnych pracowników, są formą selekcji pracowniczej. Potwierdza to fakt, iż także firmy, które jeszcze nie nawiązały współpracy ze szkołami zawodowymi, lecz nie wykluczają jej nawiązania w przyszłości, na pytanie, jak taką współpracę sobie wyobrażają, wskazują przede wszystkim na organizowanie praktyk dla uczniów/studentów. 
Instytucje, które nie współpracują ze szkołami i nie zamierzają podejmować takiej współpracy w przyszłości, jako powód braku chęci współpracy ze szkołami najczęściej wskazują czynniki bardzo ogólne (mało konkretne): brak potrzeb oraz fakt, iż firma jest zbyt mała. Wśród czynników konkretniejszych wymienia się w tym kontekście konieczność zatrudnienia pracowników z doświadczeniem, potrzebę zatrudniania pracowników o specjalistycznych kwalifikacjach, brak potrzeby zatrudniania jakichkolwiek pracowników, brak czasu na współpracę ze szkołami zawodowymi, brak wiedzy i doświadczenia w zakresie współpracy ze szkołami czy brak klas o odpowiednim profilu zawodowym. Zauważyć można jednocześnie, że ankietowani działający na terenie stref/parków zlokalizowanych na obszarze województwa podkarpackiego częściej wskazują na czynniki związane z fazą rozwoju firmy, rzadziej zaś wskazują czynniki ogólniejsze (niechęć do współpracy z systemem edukacyjnym).

Jedynie niecała jedna trzecia ogółu badanych firm zadeklarowała, iż zatrudniała uczniów/ studentów na praktykach lub warsztatach (32,8\%). Instytucje spoza stref/parków nieznacznie częściej deklarowały, iż zatrudniały uczniów/studentów w ramach praktyk lub warsztatów, niż instytucje działające w ich ramach (41,9\% wobec 30,7\%). Wśród tych ostatnich z kolei do zatrudniania uczniów/studentów częściej przyznawały się instytucje działające w par$\mathrm{kach} /$ strefach zlokalizowanych na terenie województwa podkarpackiego niż śląskiego (36,9\% wobec 25,3\%). Biorąc pod uwagę firmy zarejestrowane na terenach stref/parków, spośród dziesięciu zmiennych niezależnych ${ }^{4}$ statystycznie istotny wpływ odnotowano $\mathrm{w}$ przypadku czterech: okresu powstania firmy, obrotów osiaganych przez firmę, ogólnej liczby osób zatrudnionych w firmie oraz liczby osób zatrudnionych w ramach strefy/parku. Jednostkami najczęściej deklarującymi zatrudnianie uczniów/studentów w ramach praktyk/warsztatów szkolnych okazały się firmy powstałe między 2000 a 2004 rokiem. Deklaracje o zatrudnianiu uczniów/ absolwentów stają się tym częstsze, im wyższe obroty osiąga firma, im większą liczbę osób zatrudnia - zarówno ogółem, jak w ramach strefy/parku.

Zdecydowana większość przedstawicieli badanych instytucji zdeklarowała, iż nie zamierza w najbliższym okresie zatrudniać uczniów/studentów w ramach praktyk/warsztatów (odpowiedzi takiej udzieliło 62,99\% ogółu respondentów). Zamiar ich organizowania potwierdziło jedynie $17,08 \%$. W przypadku firm zarejestrowanych na terenie stref/parków (bez względu na województwo) odnotowano statystycznie istotny wpływ dwóch spośród dziesięciu zmiennych niezależnych, tj. (1) prowadzenia działalności jedynie na terenie strefy/parku lub także poza nią oraz (2) liczby osób pracujących na terenie strefy/parku. Firmy prowadzące działalność zarówno w ramach strefy/parku, jak też poza nimi częściej deklarują, iż w najbliższym roku szkolnym zamierzają przyjąć uczniów/studentów na praktyki/warsztaty. Zauważyć można również, iż instytucje zatrudniające 250 osób i więcej na terenie strefy/parku częściej niż pozostałe (tj. zatrudniające mniejszą liczbę pracowników) deklarują taką chęć. Tak więc firmy prowadzące szeroką działalność gospodarczą (także poza strefą) oraz przedsiębiorstwa duże częściej niż pozostałe zamierzają organizować praktyki/warsztaty dla uczniów studentów.

Instytucje, które w swej dotychczasowej działalności zatrudniały uczniów/studentów w ramach praktyk/warsztatów lub zamierzają ich zatrudnić w najbliższym roku akademickim, wskazują na dwa podstawowe motywy skłaniające ich do organizowania praktyk/warsztatów. Z jednej strony praktyki/warsztaty są okazją do sprawdzenia potencjalnych pracowników,

\footnotetext{
${ }^{4}$ Wykorzystano dziesięć następujących zmiennych niezależnych: okres powstania firmy; prowadzenie działalności jedynie na terenie strefy/parku lub także poza nim; zasięg działania firmy; obroty firmy; sektor działalności firmy; typ własności firmy; forma organizacyjno-prawna firmy; liczba osób pracujących w firmie zarówno w strefie/parku, jak i poza strefą/parkiem; liczba osób pracujących w firmie na terenie strefy/parku.
} 
z drugiej zaś chęć do ich organizowania wiąże się z możliwością refundacji części kosztów zatrudnienia. Tak więc praktyki i warsztaty postrzegane są przez pracodawców przede wszystkim jako forma rekrutacji (weryfikacji) potencjalnych pracowników oraz możliwość wykorzystania stosunkowo taniej siły roboczej.

Wśród czynników zniechęcających do organizacji praktyk/warsztatów na pierwszym planie znalazły się trzy: brak podstawowych umiejętności wśród uczniów; spadek wydajności pracy na skutek zaangażowania pracowników w praktyczne przygotowanie uczniów/studentów; konieczność pogodzenia przez uczniów/studentów pracy z nauką w szkole (brak dyspozycyjności).

Według pracodawców, na zwiększenie zainteresowania firm organizacją praktyk/warsztatów wpłynąć mogą dwa czynniki: refundacja kosztów wynagrodzenia uczniów/studentów oraz wprowadzenie odpowiednich ulg podatkowych. Są one związane z finansowym wsparciem praktyk/staży. Pozostałe czynniki - o charakterze pozafinansowym - wskazywane były wyraźnie rzadziej.

Biorąc pod uwagę niewielką liczbę firm zaangażowanych w organizowanie warsztatów/staży, nie powinno dziwić, że ponad $85 \%$ spośród badanych firm zadeklarowało, iż nie nawiązało współpracy ze szkołami zawodowym. Przy tym jedynie w 23 przypadkach kontakty te zostały sformalizowane w postaci umowy. W przypadku firm zarejestrowanych na terenie stref/parków (bez względu na województwo) odnotowano statystycznie istotny wpływ trzech spośród dziesięciu zmiennych niezależnych, tj. zmiennych związanych z zasięgiem działania firmy, z obrotami firmy oraz liczbą osób zatrudnionych w całej firmie działającej na terenie strefy/ parku. Największy odsetek wskazań „tak” odnotowano w przypadku firm o zasięgu lokalnym oraz międzynarodowym. Z kolei im większe obroty firmy oraz większa liczba zatrudnionych w niej osób (zarówno w ramach strefy, jak i poza nią), tym częstsze deklaracje o podjęciu współpracy ze szkołami zawodowymi.

Jednocześnie nieco więcej przedstawicieli firm zadeklarowało, iż gotowych jest do nawiązania współpracy ze szkołami zawodowymi, która będzie zmierzać do wsparcia procesu edukacyjnego. Gotowość taką wyraziła co czwarta spośród badanych firm. Zauważyć przy tym należy, iż niemal połowa ankietowanych zdecydowanie odrzuciła taką możliwość, zaś niemal jedna trzecia nie ma w tej sprawie jednoznacznej opinii.

Nie wystąpiły jednocześnie statystycznie istotne różnice w strukturze odpowiedzi między firmami zarejestrowanymi w ramach stref/parków a instytucjami prowadzącymi działalność poza nimi. Nie odnotowano też znaczących statystycznie różnic pomiędzy firmami zarejestrowanymi w ramach stref/parków ze względu na województwo, w którym zlokalizowany jest park/strefa. W przypadku firm zarejestrowanych na terenie stref/parków (bez względu na województwo) odnotowano statystycznie istotny wpływ jedynie jednej z wziętych pod uwage dziesięciu zmiennych niezależnych (okres powstania firmy; prowadzenie działalności jedynie na terenie strefy/parku lub także poza nim; zasięg działania firmy; obroty firmy; sektor działalności firmy; typ własności firmy; forma organizacyjnoprawna firmy; liczba osób pracujących w firmie zarówno w strefie/parku jak i poza strefą/parkiem; liczba osób pracujących w firmie na terenie strefy/parku), tj. zasięgu działania firmy. Interesujące, że największą gotowość do nawiązania współpracy ze szkołami deklarują przedstawiciele instytucji o zasięgu lokalnym.

Zauważyć można, iż zdecydowanie najbardziej popularną formą potencjalnego wsparcia procesu edukacyjnego w szkołach zawodowych jest organizowanie nieodpłatnych praktyk zawodowych. Stosunkowo często wskazywano w tym kontekście także na organizowanie odpłatnych praktyk, umożliwienie pracownikom firmy nauki zawodu w szkołach na koszt szkoły po godzinach pracy oraz promesę zatrudnienia najlepszych uczestników praktyk po 
zakończeniu nauki. Znaczące jest, iż najmniejszą liczbę wskazań uzyskały te formy wsparcia, które wiążą się z koniecznością finansowych wydatków: umożliwienie pracownikom firmy nauki zawodu w szkołach na koszt pracodawcy w godzinach pracy, zorganizowanie odpłatnych praktyk zawodowych dla uczniów/studentów fundowanych przez pracodawców, finansowe wsparcie zakupu materiałów dydaktycznych niezbędnych do praktycznej nauki zawodu, np. doposażenie warsztatów szkolnych czy umożliwienie pracownikom firmy nauki zawodu w szkołach na koszt szkoły w godzinach pracy.

Jedynie jedna piąta badanych firm bierze pod uwagę możliwość podjęcia współpracy ze szkolnictwem zawodowym oraz ośrodkami doskonalenia zawodowego przy planowaniu działań dotyczących rozwoju firmy. Niemal połowa zadeklarowała, iż nie jest zainteresowana taką formą współpracy z jednostkami edukacyjnymi. Znaczna część, niemal jedna trzecia, nie potrafiła jednoznacznie odpowiedzieć na tak postawione pytanie (wskazała odpowiedź ,trudno powiedzieć"). Nieco większy odsetek firm deklarujących gotowość współpracy z jednostkami edukacyjnymi w zakresie planowania działań dotyczących rozwoju firmy wystapił w przypadku firm z obszaru Podkarpacia. W przypadku firm zarejestrowanych na terenie stref/parków (bez względu na województwo) nie odnotowano statystycznie istotnego wpływu żadnej z wziętych pod uwagę dziesięciu zmiennych niezależnych (w każdym z przypadków poziom istotności testu chi kwadrat przekraczał wartość 0,05).

Najczęściej wskazywaną formą potencjalnej współpracy okazuje się wymiana doświadczeń i transfer technologii. Na drugim miejscu odnotowano organizowanie praktyk, staży oraz szkoleń, na miejscu trzecim zaś selekcję pracowników. Z kolei wśród czynników zniechęcających na pierwszym miejscu znalazła się ogólna odpowiedź o braku potrzeby takiej współpracy. Pozostałe przyczyny wymieniane były znacznie rzadziej (żadna z nich nie przekroczyła 10\% wskazań).

\section{Trendy na rynku pracy a ksztatcenie zawodowe}

Powyższe ustalenia wynikające $\mathrm{z}$ badań ankietowych skonfrontowano $\mathrm{z}$ wnioskami wynikającymi z analizy danych wtórnych, z których wynika, iż w ostatnich latach następuje widoczna poprawa jakościowa i ilościowa kształcenia zawodowego, a w szczególności kształcenia praktycznego, między innymi dzięki podnoszeniu się poziomu współpracy pomiędzy pracodawcami a szkolnictwem zawodowym. Program porozumień MEN z zrzeszeniami przedsiębiorców na rzecz poprawy współpracy między szkołami a rynkiem pracodawców w obszarze kształcenia zawodowego, a w szczególności kształcenia praktycznego należy uznać za godną pochwały inicjatywę wymagającą jednak uwzględnienia w kolejnych latach krytycznych uwag zgłaszanych przez środowisko szkolne i przedsiębiorców. Do głównych barier ograniczających tę współpracę należy zaliczyć: brak odpowiedniej informacji zarówno po stronie szkół, jak i przedsiębiorców, brak odpowiednich regulacji prawnych (w tym podatkowych) sprzyjających tego typu współpracy, brak środków finansowych, niedostosowanie programów nauczania do sytuacji na rynku pracy etc.

Istotną rolę w inicjowaniu i realizacji współpracy między szkołami, przedsiębiorcami i jednostkami samorządu terytorialnego odgrywają środki pomocowe UE. W obu badanych województwach można też wskazać wiele inicjatyw oddolnych tworzących tego typu współpracę zwłaszcza tam, gdzie następuje jej formalizacja w ramach „rodzących się” struktur klastrowych.

W latach 2006-2009 wzrosła liczba szkół i uczniów realizujących praktyczną naukę zawodu. Ten wyraźnie dodatni trend ma swoje przyczyny tak po stronie popytu, jak i podaży na rynku pracy. Oznacza to, że osoby wchodzące na rynek pracy (w tym również uczniowie) 
dostrzegają potrzebę lepszego (efektywniejszego) dostosowania się do jego wymogów poprzez często wąskie przygotowanie kierunkowe oraz dużą elastyczność zadaniową i szybką adaptację do nowych warunków miejsca pracy. Innym ważnym graczem rynkowym są organizacje tworzące, nadzorujące i realizujące kształcenie zawodowe. Ich aktywność związana jest m.in. z już dostrzeganą luką pokoleniową przynajmniej w niektórych zawodach, co wydaje się bardzo niebezpieczne z punktu widzenia procesów produkcyjnych. Poza tym kształcenie zawodowe zmienia swoje oblicze, oprócz edukacji formalnej, pojawiają się inne formy dokształcania, w których partycypują wspomniane organizacje. Wreszcie trzecim ogniwem rynku pracy są pracodawczy, którzy uważają, że znacznie taniej jest pozyskać pracownika o określonym poziomie wiedzy i pożądanych umiejętnościach. Coraz więcej jest przedsiębiorstw przyjmujących strategię zatrudnienia polegającą na poszukiwaniu i zatrudnianiu przygotowanych pracowników. Nie oznacza to jednak braku dalszych szkoleń w firmie, niemniej dotychczasowe wykształcenie i umiejętności stanowią pewną bazę dalszego rozwoju zawodowego. Istnieje również grupa przedsiębiorców, którzy traktują praktyki zawodowe, młodocianych pracowników i cały system szkolnictwa zawodowego, jako sposób na pozyskiwanie taniej siły roboczej.

Wzrasta liczba osób uczestniczących w aktywnych programach rynku pracy. Wydaje się, że zarówno wśród bezrobotnych (wśród których takie myślenie i działania są zwykle wymuszone), jak i wśród osób poszukujących pracy (niebędących pod tak dużą presją) rośnie świadomość potrzeby zwiększania swojej atrakcyjności na rynku pracy. Podnoszenie kwalifikacji musi jednak być związane z odpowiednim poziomem kształcenia, ponieważ tylko w ten sposób może przyczynić się do odniesienia sukcesu w poszukiwaniu pracy. Niestety efektywność szkoleń ogółem w Polsce, jak i w regionach nie jest bardzo wysoka. Wpływ na to ma bardzo wiele czynników, między innymi brak możliwości odbywania praktyk bezpośrednio po ukończeniu szkoleń. Ponadto współczesny rynek edukacyjny, w tym także rynek kształcenia zawodowego, charakteryzuje się dużą ilością instytucji i firm, których cel i zakres, a nade wszystko poziom kształcenia jest daleki od oczekiwanego. Jednostki takie, wykorzystując lukę rynkową, rosnący popyt na podnoszenie swoich kwalifikacji oraz możliwości pozyskania wsparcia finansowego ze środków UE, oferują często wiedzę encyklopedyczną, niewychodzącą poza ramy wiedzy teoretycznej, przekazywaną przez dość przypadkową kadrę. Z drugiej strony istnieje wcale nie mała grupa osób, której taka sytuacja odpowiada. Należy jednak z całą mocą podkreślić, że nie dotyczy to wszystkich tak po stronie popytu, jak i podaży. Z tych powodów z punktu widzenia norm prakseologicznych za bardziej pożądane należy uznać te programy szkoleniowe, w tym również te współfinansowane ze środków UE, których celem jest zdobycie uprawnień, certyfikatów czy konkretnych umiejętności od programów mających na celu ogólne poszerzenie wiedzy uczestników tych programów.

Dynamika gospodarki powoduje, że zapotrzebowanie na kwalifikacje i zawody podlega ciągłym zmianom. Jedne zawody będą traciły, aż do całkowitego zaniku, inne podlegały dużej dynamice wzrostowej. Niewątpliwe przechodzenie gospodarki polskiej z fazy industrialnej do postindustrialnej już odcisnęło swoje piętno na rynku pracy. Rośnie wkład sektora usług nie tylko w wytworzonym PKB, ale także zwiększa się udział osób w nim zatrudnionych w ogólnej liczbie pracujących. Nie dziwi więc fakt, że większość pożądanych zawodów na polskim i europejskim rynku pracy dotyczy sektora usługowego, w tym szczególnie handlu. Pozostałe miejsca pracy będą związane z jednej strony z wykonywaniem prostych czynności, takich jak sprzątanie, a ze strony drugiej - z zawodami naukochłonnymi. Oczywiście zapotrzebowanie na określone zawody będzie miało silne uwarunkowania regionalne, związane z bazą ekonomiczną regionu, ale również z jego strukturą demograficzną. Stąd trudno o jednolitą dla Polski 
listę zawodów deficytowych. Warto także zwrócić uwagę, że popyt rynkowy na określone kwalifikacje i zawody jest i będzie bardzo niestabilny, stąd kształcenie zawodowe musi odbywać się w systemie pull (ssanie).

W warunkach polskich główną przeszkodą w tworzeniu kompleksowej i spójnej strategii programów współpracy ze szkolnictwem zawodowym oraz programów doskonalenia zawodowego jest m.in. ugruntowana przed transformacją ustrojową i trwająca do dziś dominacja edukacji formalnej. Warto przy tym dodać, że w systemie prawnym, w działaniach administracji na różnych poziomach, działaniach instytucji i partnerów społecznych wciąż istnieje redukcja edukacji do formalnego kształcenia i szkolenia dorosłych. Jednym ze skutków tej dominacji jest opóźnienie w rozwoju uznawania kompetencji nabytych poza edukacją formalną. Ograniczenia stwarzają też skromne zasoby środków publicznych, niskie dochody ludności oraz słabość partnerów społecznych: duża część pracodawców, zwłaszcza MŚP, nie jest zainteresowana szkoleniem pracowników, zaś organizacje pozarządowe nie mają własnych trwałych podstaw majątkowych i finansowych.

Przeszkodą w tworzeniu programów współpracy jest także brak centralnych instytucji zajmujących się opracowywaniem i aktualizacją programów nauczania, określaniem profilu absolwentów różnych typów szkół oraz instytucji koordynujących działania związane z definiowaniem kwalifikacji, ich porównywaniem i uznawaniem. Stąd konieczną wydaje się potrzeba systemowych rozwiązań usprawniających współpracę między szkolnictwem zawodowym a przedsiębiorcami.

W krajach rozwiniętych, a w Polsce w okresie około 10-15 lat, należy się spodziewać głównie zapotrzebowania na zawody, które muszą być świadczone na miejscu, tj. nie doświadczą przesunięcia do państw o niższych kosztach pracy (rzemiosło, usługi naprawcze, osobiste, edukacja, rozrywka, służba zdrowia etc.) oraz zawody wymagające wysokospecjalistycznej wiedzy, głównie technicznej w branżach ciągle opierających się w dużym stopniu na działalności badawczo-rozwojowej. Dojdzie do zmniejszenia zatrudnienia w przemyśle ze względu na serwicyzację gospodarki oraz innowacje technologiczne, pracooszczędne w przemyśle.

W Europie najlepiej będą się rozwijały i zwiększały zapotrzebowanie na pracowników następujące branże: przemysł kosmiczny, przemysły audiowizualne, lotnictwo, bankowość i ubezpieczenia, obrona, ekogospodarka, usługi ochrony zdrowia, technologie informacyjne, farmaceutyki, bezpieczeństwo sieci internetowej, usługi społeczne jak opieka nad osobami starszymi i dziećmi, eksport usług edukacyjnych przy wykorzystaniu narzędzi cyfrowych, telekomunikacja jak przekazywanie głosu przez sieć szerokopasmowa, podzlecanie przy pomocy nowoczesnej komunikacji, rozwój sieci dla globalnych przedsiębiorstw, transport oraz turystyka.

Przyjmując, że branże rozwojowe to branże o rosnącej liczbie pracujących (2000-2008) oraz stanowiące specjalizację województw (w 2007 roku), w podkarpackim za takie należy uznać: przemysł meblarski, produkcję metalowych wyrobów gotowych, produkcję wyrobów gumowych i z tworzyw sztucznych, przemysł chemiczny, metalowy, przemysł drzewny, maszynowy, pojazdów mechanicznych, produkcja pozostałego sprzętu transportowego, co w tym regionie oznacza przemysł lotniczy. Z branż poza przetwórstwem przemysłowym branżami rozwojowymi w podkarpackim są handel detaliczny, wytwarzanie i zaopatrywanie w energię, gaz i wodę oraz pobór, uzdatnianie i rozprowadzanie wody. Branże rozwojowe w województwie śląskim to natomiast przemysł petrochemiczny, produkcja pojazdów mechanicznych, maszyn i aparatury elektrycznej, metalowych wyrobów gotowych, a także, choć w mniejszym stopniu, przemysł skórzany. Z branż poza przetwórstwem przemysłowym zwiększyły liczbę pracujących i stanowią specjalizację regionu gospodarka ściekami i odpadami oraz pozostała działalność usługowa. 
Na tle innych sekcji w latach 2003-2008 przetwórstwo przemysłowe w województwie śląskim miało wyższą średnioroczną dynamikę przychodów od pozostałych sekcji, poza budownictwem oraz ochroną zdrowia i opieką społeczną. W podkarpackim natomiast szybszy średnioroczny przyrost przychodów niż przetwórstwo przemysłowe cechował budownictwo, handel i naprawy, transport i łączność, obsługę nieruchomości i firm oraz ochronę zdrowia i opiekę społeczną. Za branże liderów w latach 2000-2008 w województwie podkarpackim pod względem wyników finansowych należy uznać z przetwórstwa przemysłowego produkcję wyrobów chemicznych, produkcję mebli, pozostałą działalność produkcyjną oraz produkcję pojazdów samochodowych, przyczep i naczep. W województwie śląskim w latach 2002-2008 najszybszy średnioroczny przyrost produkcji sprzedanej cechował branże wysokiej techniki: przemysł instrumentów medycznych, precyzyjnych i optycznych, produkcję sprzętu RTV, a także branże średniowysokiej techniki: przemysł elektryczny, maszyn i urządzeń, pojazdów mechanicznych. Z branż niskiej i średnioniskiej techniki najszybciej wzrastała produkcja wyrobów gumowych i z tworzyw sztucznych, metalowych wyrobów gotowych oraz w przemyśle meblarskim.

Na podstawie danych urzędów pracy za zawody i specjalności deficytowe, tj. takie, w których więcej jest ofert pracy niż osób jej poszukujących, w województwie śląskim w 2008 roku uznać można: spawacz ręczny łukiem elektrycznym, brukarz, robotnik gospodarczy, spawacz ręczny gazowy, elektromonter instalacji elektrycznych, kierowca operator wózków jezdniowych, pozostali robotnicy przy pracach prostych w przemyśle, monter sprzętu gospodarstwa domowego, cieśla, robotnik budowlany, pracownik biurowy, pracownik ochrony mienia i osób, dekarz, kierowca samochodu ciężarowego, operator suwnic (suwnicowy), sekretarka, pakowacz, przedstawiciel handlowy (przedstawiciel regionalny), rozbieracz - wykrawacz, magazynier, pozostali operatorzy maszyn gdzie indziej niesklasyfikowani, posadzkarz, robotnik magazynowy, robotnik drogowy, frezer, pracownik administracyjny, księgowy (samodzielny), murarz, monter instalacji wodociągowych i kanalizacyjnych, sprzątaczka, kierowca samochodu osobowego. W I kwartale 2009 firmy zgłaszały największe zapotrzebowanie na stanowiska pracownika produkcyjnego w zakładach przemysłowych, fizjoterapeutów, tapicerów, sprzedawców, monterów oraz kierowców.

Według danych uzyskanych na temat prognozowanego popytu na kwalifikacje w województwie podkarpackim do 2013 roku największe zapotrzebowanie będzie na kwalifikacje niezbędne do wykonywania następujących zawodów powiązanych z przemysłem: sprzedawcy i handlowcy, specjaliści marketingu i handlu, operatorzy sprzętu komputerowego, informatycy, specjaliści obsługi i administrowania usług internetowych, specjaliści systemów komputerowych, elektronicy, elektrycy, operatorzy linii produkcyjnych i robotów przemysłowych, mechanicy-operatorzy maszyn i urządzeń (także sterowanych numerycznie), robotnicy obróbki drewna, stolarze meblowi, cieśle, mechanicy maszyn i urządzeń, pracownicy ochrony, pracownicy do spraw finansowych i statystycznych, ekonomiści-finansiści, księgowi/analitycy finansowi, pracownicy obrotu pieniężnego, doradcy inwestycyjni, doradcy biznesowi, specjaliści nauk społecznych, architekci, projektanci i inżynierowie budownictwa, specjaliści budowlani, robotnicy budowlani, pracownicy obsługi biurowej, asystenci-sekretarz administracji, specjaliści bezpieczeństwa i jakości, doradcy ekologiczni i ochrony środowiska, inżynierowie i robotnicy obiektów ochrony środowiska, spawacze i ślusarze, specjaliści obróbki skrawaniem i obróbki metalu, piekarze, cukiernicy, kierowcy samochodu ciężarowego.

W przypadku instytucji animujących kształcenie zawodowe (w tym szkoły, kuratoria, zrzeszenia pracodawców) powinno się zwiększyć nacisk na rozpoznanie potrzeb lokalnych rynków pracy, a w miarę możliwości na jego zaspokajanie. Adresatem tego typu działań powinni 
być uczniowie i to już w momencie podejmowania nauki w gimnazjum, nie zaś na ostatnim jej etapie. Mowa tutaj o:

1. szeroko rozumianej akcji informacyjnej o warunkach, miejscu i specyfice pracy w poszczególnych zawodach, która powinna być prowadzona w formie systematycznego doradztwa zawodowego (najlepiej już od 2 klasy gimnazjum). Konieczne jest więc skuteczne promowanie kształcenia w szkołach zawodowych, zwiększenie dostępu młodzieży do informacji o specyfice zawodów oraz o potrzebach rynku pracy, tak aby absolwenci gimnazjów mogli świadomie planować karierę zawodową;

2. zachętach, w tym finansowych, tj. między innymi stypendiach dla uczniów podejmujących naukę w zawodach deficytowych;

3. ułatwieniach w możliwości odbywania staży zawodowych w renomowanych przedsiębiorstwach zgodnie z profilem kształcenia.

Optymalnym rozwiązaniem byłoby wprowadzenie kształcenia dualnego, a więc - w pewnym sensie - powrót do modelu kształcenia zawodowego sprzed reformy edukacyjnej w 1997 roku. Niestety rozwiązanie to wiąże się z konieczności ponoszenia zdecydowanie większych nakładów finansowych ze strony państwa.

Poważnym problemem pozostaje fakt braku stymulacji procesów dostosowawczych w szkolnictwie zawodowym poprzez algorytm alokowania środków publicznych, dla którego najważniejszym kryterium jest liczba uczniów/studentów. W tym kontekście niezbędne jest uzależnienie finansowania szkół/uczelni od losów absolwentów na rynku pracy. Istnieje więc konieczność wprowadzenia powszechnego monitoringu losów zawodowych absolwentów oraz systemowego powiązania dotacji budżetowej dla szkół/uczelni z losami absolwentów na rynku pracy.

Działania instytucji związanych z kształceniem zawodowym powinny objąć także samych pracodawców. Również w tym przypadku potrzebna jest akcja informacyjna, ponieważ wśród pracodawców zdaje się ciągle funkcjonować kilka stereotypów dotyczących zatrudniania młodocianych pracowników. Tymczasem formowanie postawy pracownika od najmłodszych lat powoduje nie tylko większe prawdopodobieństwo lojalności, ale przyczynia się do bardziej efektywnej i mniej konfliktowej pracy w dalszych latach kariery zawodowej. Poza tym wydaje się, że z racji trudności związanych z niskim poziomem wiedzy ogólnej uczniów i często niedopasowanym systemem kształcenia, warto pracodawcom uświadomić, iż trafny nabór i selekcja pracowników w najlepszy sposób może dokonywać się właśnie w trakcie praktyk i szkoleń. Fundamentalną sprawą wydaje się jednak wprowadzenie systemu finansowych zachęt motywujących pracodawców do organizowania praktyk i staży dla uczniów i studentów, co także wiąże się ze zwiększeniem nakładów finansowych ze strony budżetu państwa.

Ograniczeniu ww. wydatków sprzyjałoby wprowadzenie systemu polegającego na zawieraniu przez przedsiębiorców kontraktów z wybranymi uczniami. Przedsiębiorcy finansowaliby ich szkolenia i kursy zawodowe w trakcie edukacji szkolnej, natomiast uczeń po zakończeniu edukacji odpracowywałby na rzecz przedsiębiorstwa poczynione na niego nakłady finansowe. System taki umożliwiłby uczniom zdobycie jak najlepszego wykształcenia praktycznego oraz zagwarantowałby im zatrudnienie po zakończeniu szkoły. Przedsiębiorca natomiast zyskałby pewność zatrudnienia dobrze przygotowanego pracownika zarówno od strony merytorycznej, jak i praktycznej znajomości środowiska pracy.

Istnieje konieczność podjęcia działań na rzecz doskonalenia formuły egzaminów zewnętrznych potwierdzających kwalifikacje zawodowe oraz podniesienia świadomości pracodawców na temat istnienia zewnętrznego egzaminu zawodowego tak, aby mógł być w przyszłości atutem ułatwiającym pozyskanie pracy. Wydaje się, iż obecny kształt egzaminu potwierdzającego 
kwalifikacje zawodowe w części praktycznej, która w technikach w niektórych zawodach ma charakter teoretyczny, ma niewielki związek z praktyką i sprawdza tylko poziom realizacji podstaw programowych, a standaryzacja zadań oddala egzamin od wymagań rynku pracy. W celu poprawy efektywności kształcenia praktycznego konieczne jest także zwiększenie możliwości odbywania praktyki gospodarczej u przedsiębiorców przez nauczycieli przedmiotów zawodowych.

\section{Podsumowanie}

Będąc u progu epoki społeczeństwa informacyjnego, za ważne, jeśli nie najważniejsze, uznaje się kształcenie przez całe życie. Jednym z jego ogniw są kursy i szkolenia. Ich ranga w przyszłości będzie wzrastała, zatem im szybciej wszyscy aktorzy gry rynkowej uświadomią sobie ten fakt, tym lepiej. Zważywszy na dynamikę rynku pracy, istnieje duże zapotrzebowanie na kursy i szkolenia. Należy jednak wyeliminować pewną doraźność i przypadkowość ich organizowania. Potrzeba zatem większej informacji o ich realizacji zwłaszcza na poziomie lokalnym, ponieważ w skali województwa ma miejsce wiele sytuacji patologicznych. Organizowane kursy powinny być dostosowane do zapotrzebowania pracodawców. Otóż złym zwyczajem jest organizowanie kursów bez przynajmniej częściowej znajomości potencjalnego popytu rynkowego. System edukacyjny (a także system dokształcania i przekwalifikowywania) nie dysponuje informacjami o bieżącym i perspektywicznym zapotrzebowaniu na zawody i specjalności, przez co instytucje rynku pracy, edukacyjne oraz szkoleniowe nie są w stanie w stopniu zadowalającym realizować swych zadań (tj. kształcić w takich zawodach lub/i kierować bezrobotnych na takie szkolenia, po których będą mieli szanse zatrudnienia). Istnieje więc konieczność wypracowania i wdrożenia odpowiedniej metodologii zbierania, analizowania oraz upowszechniania takich informacji.

W wyniku labilności zapotrzebowania na kwalifikacje i zawody niezbędny jest permanentny monitoring rynku pracy. Wydaje się, że tego typu zabiegi odbywają się na poziomie kraju czy województw, jednak dużo rzadziej mają miejsce na poziomie gmin i powiatów. Należy zatem zwiększyć rozeznanie lokalnych rynków pracy, także dlatego, że przy ujęciach wojewódzkich opóźnienie diagnostyczne, a następnie opóźnienie wdrożeniowe jest znacznie dłuższe. Powszechnie znanym jest fakt, że zapotrzebowanie na zawody i kwalifikacje na rynku pracy w następnych latach będzie zmieniało się bardzo dynamicznie. Istnieje zatem potrzeba pewnych działań wyprzedzających, które pozwolą na szybsze dostosowanie się popytu do podaży. Jednak bazą takich działań jest możliwie pełna diagnostyka zjawiska, która w następstwie umożliwi zastosowanie metod prognostycznych (w tym ekstrapolacyjnych).

Konieczne wydaje się przygotowywanie profesjonalnych prognoz popytu na pracę w perspektywie kilku lat, powiązanych zarówno ze strategią rozwoju gospodarczego kraju, jak i strategiami regionalnymi, w celu trafnego, właściwego planowania kierunków kształcenia w zawodach odpowiadających potrzebom rynku pracy. Głównym wyznacznikiem dla kreowania kierunków kształcenia w szkolnictwie zawodowym powinny być potrzeby przedsiębiorców działających w danym regionie. Planowanie kierunków kształcenia w zawodach odbywa się z dużym wyprzedzeniem, a ich absolwenci wchodzą na rynek pracy minimum po 4 latach nauki. W związku z powyższym, uruchamiając kierunki kształcenia zawodowego, konieczne jest prognozowanie popytu na pracę w tych zawodach w perspektywie co najmniej 5 lat.

Ponadto można kreować listę zawodów pożądanych w danym regionie, zważywszy na strategię rozwoju województwa. Uruchamiając listę preferencyjnych zachęt inwestycyjnych dla określonych sfer działalności, można w ten sposób przygotowywać dla nich kadry. 
Poza monitorowaniem rynku pracy należy już dzisiaj przygotowywać się do ograniczenia zatrudnienia w przemyśle, szczególnie pracochłonnym, przez zmianę kierunków kształcenia na dziedziny, w których prognozowane jest zapotrzebowanie. W tym celu ważne jest m.in. stymulowanie przedsiębiorczości osób, gdyż wiele z zawodów przyszłości to usługi, które mogą być świadczone w ramach działalności gospodarczej prowadzonej przez osobę fizyczną. Należy też dbać o rozwój wysokospecjalistycznej kadry dla branż wysokiej techniki poprzez lepsze kształcenie w zakresie nauk ścisłych w programach edukacyjnych.

Branże te mogą stanowić potencjalne klastry w regionach i być lokomotywami rozwoju regionów. Ważna jest więc dbałość o zapewnienie im pracowników o wymaganych kwalifikacjach, zarówno poprzez system edukacji, jak też przez uzupełnianie kwalifikacji pracowników w ramach szkoleń.

\section{Literatura}

1. Cyrson E., 2009, Przedsiębiorstwo w otoczeniu wpół zglobalizowanym [w:] Przedsiębiorstwo w otoczeniu globalnym. red. O. Dębicka, A. Oniszczuk-Jastrząbek, T. Gutowski, J. Winiarski, Wyd. UG, Gdańsk.

2. Timmermans K., 2005, Sekrety tanich dostaw, „Outlook”, nr 1.

3. Źródła i strategie innowacyjności przedsiębiorstw, 2005, Wyd. The Conference Board, Warszawa.

\section{The Effectiveness of Special Economic Zones, Science and Technology Parks, Industrial Parks in the Light of the Demands of Companies for Human Resources on the Example of Silesian and Podkarpackie Voivodeships}

The article aims to present the result of surveys and secondary data, which were to identify the future needs of employers and investors in the work force (specification of the necessary qualifications and the level of previous experience) in the short term (up to 1 year) in the labor market in the Silesian and Subcarpathian region.

The study found that people entering the labor market (including students) recognize the need for a greater adaptability to market requirements. Therefore, we may note an increased number of people participating in active labor market programs. Unfortunately, the total efficiency of training in the regions concerned is not very high. Thus, vocational training must change its image, although sometimes this process is occurring far too slowly. The third link in the labor market are the employers who recognize the fact that it is much cheaper to acquire an employee with a certain level of knowledge and skills. Unfortunately, for some employers apprenticeships, young workers and the entire system of vocational education are seen as a way to attract cheap labor. Yet the developing process of globalization, the stage of advancement of the socio - economic as well as the dynamics of the economy itself that stimulate the demand 
for skills and jobs are constantly changing. The most desirable professions in the Polish and European labor market concern the services sector including, in particular trade. Other jobs are and will be linked, on the one hand, with simple operations such as cleaning and, on the other hand, with the scientific professions. Of course, the demand for certain professions will have strong regional circumstances related to the economic base of the region as well as the demographic structure. Hence it is difficult to make a single list of deficit jobs for Poland. It is worth noting that the market demand for certain skills and occupations is and will be unstable, so any training must take place in the system of pull (suction). 